\title{
VARIATION, CONTACT AND CONVERGENCE IN FRENCH SPOKEN OUTSIDE FRANCE
}

\author{
Françoise Gadet \& Mari C. Jones \\ Université de Paris-10, France \& University of Cambridge, UK
}

French is a highly suitable candidate for the study of language contact since, everywhere apart from in France ${ }^{1}$, it is 'in contact', with one or more languages. Moreover, it always stands in either an institutional or a de facto dominated position; and indeed, in some American and even European contexts - such as Newfoundland, New England, Missouri or the Channel Islands - it is obsolescent. The aim of this paper is to examine the relationship that exists between variation and interference, at a syntactic level by considering issues such as how contact affects the scope of variation within the French language, taking the latter in its widest possible meaning.

\section{Theoretical Considerations}

\subsection{Variation and contact}

The dichotomy between the internal variation of a language and the effect of contact is an interesting one. Considered in its 'panlectal' entirety, the variation apparent in the French outside France displays simultaneously both convergent and divergent features, of which the latter will be considered in this paper. However, to see a language as an independently-evolving system would be to disregard the fact that its primary function is that of communication and that it is therefore being constantly manipulated by its speakers who, by this very action, are influencing its development (cf. Farrar \& Jones 2002:2). As the sociologist Erving Goffman would put it, language contact happens as a consequence of the multiple ordinary adjustments between speakers, in different language situations (what he called footing). This paper therefore also raises the question of whether grammatical data can justifiably be studied in isolation or whether it is also necessary to consider the sociolinguistic context. Although such a strategy might seem self-evident, it is worth noting

\footnotetext{
${ }^{1}$ Of course, the very act of considering languages at a 'national' level could be criticized as something of an over-simplification: for example in Switzerland, most French speakers do not in fact live in a bilingual context. Furthermore, it could be said that French also exists in a situation of language contact within in France as: 1) no truly isolated languages exist and 2) in France, many speakers speak a language other than French (a regional or immigrant language). However, the positions of French wiithin and outside France are undoubtedly quite different, as the fact of being in a dominant or a dominated context carries with it different structural consequences for a language and for its speakers.
} 
that, despite its increasing recognition as a trigger for change, many general accounts of language change attempt to justify neglecting factors which pertain to the social characteristics of situation in which speakers interact. Uriel Weinreich, generally considered to be the first 'theoretician' of language contact, was clearly focussing mainly on structural principles rather than on sociolinguistic considerations when he wrote that "In the interference of two grammatical patterns it is ordinarily the one which uses relatively free and invariant morphemes in its paradigms which serves as the model for imitation" (1953:41) and the same underlying thoughts are also explicitly formulated in more recent work. Lass, for example, has stated : "Neither language-users, nor their internal states ought to be the main focus of attention, if our aim is to explain [...] change, since change itself is a built-in property of the kind of system that a human language [...] happens to be" (1997:386).

The following discussion will focus mainly on syntax and a phenomena which has been termed 'multiple causation' (Thomason \& Kaufman 1988:57) ('surdétermination' or 'renforcement' in French) and which could be defined as when the occurrence of language change can conceivably admit more than one motivation. We will focus primarily on instances where this leads to convergence of sorts between the structure of English and French, when a particular form is maintained in French in preference to another-the motivation for which often lying in the fact that it resembles a structure of English.

Not everything in a language can be variable, and the areas of grammar which are typically so are not generally documented in grammar books. This observation led the great $20^{\text {th }}$ century linguists Roman Jakobson and André Martinet to propose a model that differentiated between the hard core areas ('noyau dur') of a linguistic system that are usually invariable, and what they call its weak points ('points de faiblesse ou de fragilité du système'), namely those displaying variation, where reconfigurations are more or less constant. In the French context, it is interesting to note that most processes of reconfiguration that have occurred between the $17^{\text {th }}$ century and the present day have tended to involve the same areas of grammar. Although optimality (or, less restrictively, 'autoregulation', as Chaudenson puts it) may play a part, this cannot be seen as the sole motivating process, as social factors are constantly impacting upon linguistic variation.

If this leads us to raise the question of whether the term 'variation' itself would benefit from a more rigorous definition, then we might also devote some attention to exactly what we mean by 'contact'. Although both terms are widely used in the literature according to well-established conventions, the wide range of meanings that they carry can, at times, prove unhelpful. As considerations of space preclude a longer discussion of this point, the definition of contact in Thomason (1997:9) will be adopted, namely "Contact is a source of linguistic change if it is less likely that a given change would have occurred outside a specific contact situation". Extending this more specifically to syntax, it may be useful to add a working definition of 'convergence', as "the loss of a native form without counterpart in the other language, to the benefit of a form having a counterpart in the dominant language" and to highlight the distinction between reductive changes (frequent in obsolescent languages - cf. Sasse 1992:77) involving the "actual loss of some part of the language - or more precisely a loss of some part of a component of the grammar without resulting complication of another component to make up for this loss" (Mühlhäusler 1974:22) and what would be merely simplification, involving reorganization (again, primarily in obsolescent languages) or restructuring.

The points addressed will therefore be the following: 1) Does grammatical borrowing ever happen? (see, for example, Johanson (2002) or Sankoff (2001) for a general overview or Vinet (1996) for Quebec French, all of whom agree that, if it exists at all, syntactic borrowing is relatively uncommon); 2) In which areas of the syntactic component of a language would borrowing be most likely to occur? 3) Are these the same areas that typically also display intrasystemic variation and, if 
not, where do the differences lie? 4) Is it possible to claim that borrowing can exert a regulatory effect upon the system?

\subsection{Geographical areas}

The following discussion focuses mainly on varieties of French spoken in North America and in the Channel Islands varieties of French. In each case, the contact language is English which, typologically speaking, does not vary greatly from French, but from which it often diverges. Our rationale for choosing such geographically distant varieties it to emphasise the fact that syntactic developments of the kind we are describing is no way localized phenomena, and may be found in the French of at least two different continents. As mentioned above, the focus of the paper is primarily syntactic. Morever, precedence is given to linguistic rather than sociolinguistic phenomena, the latter being more clear-cut as they often involve considerations such as usage, setting, and conditions of acquisition. Given our predominantly syntactic approach, we have not deemed it necessary to enter into discussion of either 1) the precise sociolinguistic situations of the varieties in question - which, to the eye of the sociolinguist, might well appear too simplistic in nature (especially as regards issues such as the difference between 'healthy' and obsolescent varieties); 2) the different historical situation of French in these contexts, and specifically in the Channel Islands and in North America ${ }^{2}$.

Although of undoubted interest to the topic of 'panlectal' variation in French (i.e. all possible varieties of French - cf. Gadet 2006), data from African varieties of French (the Maghreb and socalled Black Africa) will not be discussed in this paper. This is in order to avoid muddying the waters by introducing other factors that can lead to divergence, such as the precise nature of the transmission chain or the number and the typological features of the languages in contact $^{3}$.

\section{Some interesting grammatical features}

We will now consider some features of those areas of the French language that seem most prone to variation and which have been selected on the basis of their different linguistic properties. Of these, the verbal system is the most strongly structured, clitic pronouns and adjectives are somewhat less so, prepositions are closer to the lexicon (if they can be said to form a system, then it would be a more open one), forms such as back or comme do not form part of any system; and que-phrases form part of the syntax of complex structures.

\subsection{The verbal system}

The generalization of avoir as an auxiliary (to all verbs, even those taking être in standard French as well as in the ordinary use of most France French speakers) is commonly found in many contact varieties of French. This could at first sight be considered as influence from English (witness Mougeon's study of Ontarian French, as presented in Chaudenson et al. 1993).

Contact-induced influence could also be mooted to account for the increasingly infrequent use of the subjunctive in the obsolescent French dialects of the Channel Islands, where it is both decreasing in usage and also being replaced by the conditional (Jones 2000 [Guernsey], 2001:114118 [Jersey]). A similar development has also been observed in obsolescent Louisiana French

\footnotetext{
${ }^{2}$ Whereas the varieties of French spoken in the Channel Islands are dialects of Norman French, those of North American have their origin in Colonial French, likely to be related to the Popular French of the $16^{\text {th }}-18^{\text {th }}$ centuries, and having very probably undergone a process of koneization. The only North American variety of French to show more salient dialect features is Acadian (in its Canadian as well as Louisiana versions).

${ }^{3}$ We acknowledge that this decision may be questionable and will return to it in the conclusion. Due to its problematic nature, the term 'native speaker' has been avoided in this paper.
} 
(Neumann-Holzschuh 2005), where it can be replaced by different grammatical forms, in particular the infinitive. It may even be found in 'healthy' varieties such as Quebec French (Laurier 1989), where it is found mostly (if not exclusively) after il faut que and some common verbs such as vouloir.

However, closer examination reveals that both developments are also found in varieties of French having no obvious contact with English: for example, both were noted by Bauche as long ago as 1920 as characteristic of français populaire (spoken in Paris); and both are also attested in Quebec French (see Sankoff \& Thibault 1977 for avoir). Moreover, both phenomena could be seen as the internal simplification of a more complex distribution pattern. Although therefore, it might be possible to posit that, in the above cases, a convergence of sorts is occurring between the corresponding structures of English and French, an internal explanation is not impossible either. Accordingly, it might be imprudent to venture an exclusively external explanation.

\subsection{Clitic pronouns}

Many North American varieties of French have an apparent tendency to eliminate anything that contravenes SVO (subject-verb-object) word order. This is particularly true with pre-verbal object clitics, hence St. Fr. il nous parle is realised as il parle à nous-autres (Louisiana, Rottet 2001, 2005), cf. also St. Fr j'y vais as je vais là (Ontario); St. Fr. je le fais as je fais ça (Louisiana) etc. As clitics and nouns follow the same word order in English, the ordering of these varieties could be considered as contact induced.

Clitics in French show three contradictory trends (Chaudenson 1998): reinforcement (mainly with regard to subjects, as in nous-autres, attested in several extra-Hexagonal varieties: nous-autres faisons, and even nous-autres fait (Louisiana); replacement (as in je vais là, — generally with a change of word order), and deletion, particularly with respect to object clitics (as in il fallait lui couper and not il fallait la lui couper). As all these phenomena can be said to involve simplification, and are also found elsewhere in the French-speaking world (for example in Belgium, or in France), the innovative word orders in examples of this kind could also be seen as internallymotivated (reinforcement) rather than as borrowings. It is worth noting, however, that other examples found in obsolescent varieties of French can clearly be attributable to contact, for example ma mère me fait manger z'en (Newfoundland, King 1989), which could, according to King, be influenced by the English construction 'eat some (of it)').

\subsection{Adjectives}

In both mainland Norman and Guernesiais, unmarked qualificative adjectives, especially those of colour, often precede the noun, whereas other types of adjectives are generally postposed. However, modern Guernesiais displays an increasing tendency towards preposing all adjectives, even compound adjectives, which are usually longer and therefore more likely to follow the noun in mainland Norman : Ses anti-rouoyalistes principes; Ches prumière génératiaon Méthodistes.

Despite the inclination to attribute the tendency towards pre-posing adjectives in Guernésiais to contact with English (where adjectives are always preposed), the data also conceivably admit an internal explanation in that this order already exists in the dialect, albeit in a restricted context (mainly with adjectives of colour). It could be, therefore, that the simplificatory change from having two possible adjective positions to only one is an internal change in progress in the dialect and that the fact that preposing of adjectives is the strategy also used by English may be a factor favouring the 'winning out' of preposed over postposed adjectives as part of this process (cf. Lass 1997:200). In this case, too, then, we have two possible explanations for the change or, what is also likely, two mutually-reinforcing processes - and this even in an obsolescent variety where one might assume a contact-based explanation. 


\subsection{Infinitival constructions involving a subject}

The non-standard construction passe-moi le journal pour moi lire (literally 'give me the newspaper for me to read') has been frequently discussed by grammarians. The first linguist to describe it, Louis Remacle (1952), considered it to be a Belgicism, occurring as a product of contact between French and the Germanic language spoken in the northern part of Belgium, Flemish. Today, it is relatively easy to know that this construction is not specifically Belgian (unsurprisingly, as languages do not usually respect political borders) and that it is also found over a large part of north-eastern France, in Lorraine and in Alsace). Interestingly, it is also present in the variety of French spoken in Louisiana, for example il a fait un gros plancher pour nous-autres danser dessus (Stäbler 1995). Given that no obvious historical connection exists between Belgium and Louisiana, as most of the emigrants from the first diaspora came from the West of France (Normandy, Brittany, Poitou), it is possible to speculate that this construction might have arisen as a means of avoiding the subjunctive, with its highly irregular conjugation (see Neumann-Holzschuh 2005 for the French of Louisiana). Brasseur's (1998) study of Newfoundland French has also revealed sequences such as $i$ se ramassiont dans les maisons veiller (Newfoundland), which he calls a 'substitute infinitive', or 'a verbal form as bare, as reduced as possible'.

It is therefore again possible to venture a non-contact, or internal, explanation for pour moi lire type constructions as they can also be analysed as: 1) simplified (avoiding the complex conjugation of the subjunctive), 2) more explicit than a bare infinitive, because they explicitly formulate the (usually implicit) subject (avoiding the potential ambiguity of some segments: pour que je lise or pour que quelqu'un d'autre lise). They are certainly not direct borrowings, but could perhaps be reinforced by contact with a Germanic language. We should not therefore discount an external motivation completely.

\subsection{Prepositions}

It is still unclear as to whether some cases of non-standard prepositional usage are in fact, archaïsms, examples of structural reorganisation or borrowings from English. Prepositions constitute one of the most variable areas in French, even in the variety spoken in France (where hesitation may occur between $\grave{a}$, de and $\varnothing$ ), possibly since they represent a major structural reorganization from the case-based mother tongue, Latin.

- Some instances of prepositions are undoubtedly borrowings, occasionally with no obvious structural motivation (aller sur un voyage, ' to go on a trip'), whereas others are easier to account for, such as when the French system offers no easy formulation, for example l'appareil est dessus ou sur (both prepositions may be borrowed from English, 'it is on', (Ontario; Mougeon in Chaudenson et al 1993) (cf. St. Fr. l'appareil est sous tension, which sounds rather technical). Forms such as j'ai attendu $10 \mathrm{mn}$ pour l'autobus ('to wait for'), could conceivably be due to interference (for example when found in Alsace, interference with the Germanic substrate variety, Alsatian, which shows many structural similarities with German - the latter has 'warten auf' in such a context), but do however also highlight an obvious 'deficiency' in French, namely the imprecise nature of transitive constructions with different kinds of objects). ${ }^{4}$ Furthermore, given that the insertion of prepositions in such contexts is far from uncommon in français populaire (for example chercher après quelqu'un), constructions such as attendre pour are less surprising than they might initially seem. Once again, this form could be a product of competing or reinforcing motivations (intrasystemic weakness + intersystemic convergence).

- Differentiation of prepositions. Guernésiais has two different forms of the preposition 'with'.

\footnotetext{
${ }^{4}$ Compare je mange une pomme and j'attends l'autobus : the effect of the verbal process on the object differs in each case.
} 
Dauve, which is the unmarked form (Counnis-tu chutte belle garce dauve l's bllus iaers? 'do you know that pretty girl with the blue eyes?') and atou, used when expressing an instrumental function such as J'ai copaï le pôin atou le couté 'I cut the bread with the knife'. This differs from both English and Standard French, where one preposition (with/avec) is used for both functions. However, data collected from the modern dialect revealed a widespread simplification of the system in this context, with the generalised use of dauve to most contexts (Jones 2002:157). The loss of this preposition may be seen either as convergence to the English prepositional system or as evidence of internal change, with the simplification of a complex distribution pattern.

- Preposition stranding which, in France, is heavily constrained (either to some prepositions, or according to whether the following noun is animate or inanimate ${ }^{5}$ ), is much more common in North American French (Roberge \& Rosen 1999). Its frequency is often attributed to borrowing from English, but many of the examples found in, for example, Acadian French do not form a match with any English structures. In Acadian French, preposition stranding has not been found with $\grave{a}$ or de, other than in a few examples from Prince Edward Island French, an obsolescent variety where borrowing is heavy. For example, qui c'est que t'as été à Ottawa au travers de ? - King \& Roberge (1990), meaning 'through whom (i.e. with whose help did you go to Ottawa?'), is very probably an example of interference (although possibly not a direct translation). For Roberge \& Rosen (1999), the 'gaps' pre-supposed by the stranding process do not have the same origin in English and in French (proceeding in the latter from resumptive, omittable pronouns, whereas in the former they are the product of displacement). However, despite appearances, an interference-based explanation can only account for cases such as these at a superficial level. In $17^{\text {th }}$ century French, the range of syntactic possibilities was greater: viens-tu avec? (literally, 'do you come with?') could be used even when the subject in question was a person (Brunot \& Bruneau 1956), something that would later be condemned via normative interventions by purist grammarians. Since preposition stranding is relatively uncommon among languages (Roberge \& Rosen 1999), it would be difficult to explain why French would have borrowed such a feature from English, even in high-contact situations.

\subsection{Relatives, and que-deletion}

Que-deletion in French is often attributed to influence from English (cf. the man I saw; I think he came) and, until recently, it was often described as characteristic of North American French. However, analysis of modern corpora has revealed that it is also frequent in the colloquial French of France: tu veux je vienne? (Paris; example from Bauche 1920); c'est maintenant tu l'entends? ça fait longtemps elle est sortie (français populaire, Paris) and therefore cast some doubt upon the likelihood of a purely external explanation ${ }^{6}$.

Other examples, cited by King (1991), do undoubtedly represent 'true' borrowings, and sometimes even reveal que-'doubling' : l'argent which qu'il a donné (Prince Edward Island French). It may be no accident that such 'true' borrowings occur in an obsolescent variety, although internal explanations are not necessarily ruled out automatically in such varieties (see 2.3. and 2.5. above). It is more difficult to establish that instances of que-deletion in low-contact languages represent borrowing or interference.

\footnotetext{
${ }^{5}$ In Hexagonal French, je voyage avec cannot suppose avec ma femme (but this is changing among young French people, and there is no such restriction, for example in Switzerland).

${ }^{6}$ Given the syntactic focus of this paper, the origins of que-deletion (namely, whether it already existed in popular French in 17th-18th century and was to be found in the French of the immigrants) will not be considered here.
} 


\subsection{The particle back}

The presence of the particle back in Acadian French is generally attributed to intensive contact with English. It is known to occur in several North American varieties of French, ${ }^{7}$ but its function in 'Chiac' is particularly noteworthy. ${ }^{8}$ However, Tremblay (2005) has shown that borrowing from English is not the only possible explanation here, and indeed probably not even the best one, for at least 3 reasons : 1) the distribution of back is not the same in English as it is in Acadian French (its use is wider in the latter, for example je voulais pas back aller, whose pre-infinitival use in this context has no counterpart in English); 2) the meaning is not identical in both languages (once again, it is broader in Acadian French); and 3) back does not behave like the other particles directly borrowed from English by Chiac French (for example, up or out, in finder out, on les frig pas up see Chevalier et al. 2005).

This use of back may, in fact, go some way towards solving the problem posed by the ambiguity of Standard French revenir - 'come for the second time', or 'go in the reverse direction'). Tremblay (2005) suggests that relexification may have taken place: namely, that of a former particle arrière (used, for example, in et cil vont arrière à la nef, 'they go back to the ship'), which, at the end of the Middle Ages, disappeared from Standard French but not from some of the dialects spoken in France. It is possible that the form may have been taken to Canada by immigrants. ${ }^{9}$

\subsection{A particular use of comme}

Non-standard uses of comme are found in Chiac, but also in the French of Quebec. Perrot (1992), and Chevalier \& Cossette (2002) claim that all French speakers, even if they are not from North America, will have a general understanding of the use of comme in the Acadian French of New Brunswick (in constructions such as ça fait comme dix minutes qu'on parle, Perrot 1992), although not necessarily a sophisticated and precise one). ${ }^{10}$ Whether or not such usage is in any way related to that of English like remains to be determined. It therefore seems that the putative influence of like cannot be categorically rejected but it remains to be explained why it would be French comme and not English like (the latter never being found in constructions of this type) which is used, especially since this variety does frequently borrow connectors such as but, so, whatever, anyway, well, who cares, ${ }^{11}$ and so forth. For these reasons, Chevalier \& Cossette and also Perrot refute any possible English influence.

\section{Conclusions : what lessons can be drawn from contact?}

The examples discussed in section 2 have demonstrated that 1) it is difficult to separate out internal and external factors in language change in terms of their effects on the structure of certain varieties of French and 2) these processes are certainly not exclusive. Moreover, claims such as that

\footnotetext{
${ }^{7}$ According to Rottet (2005), this use of back in the French of Louisiana is documented as early as 1932.

${ }^{8}$ Chiac is a mixed language spoken by young people in the Moncton area of New Brunswick. It is French based but its lexicon is heavily anglicised : j'ai watché le show à la $T V$ - as are some of its grammatical features. See Perrot (1992).

${ }^{9}$ Insofar as sociolinguistic reasons of transmission are concerned, we remain to be totally convinced by Tremblay's argumentation, but find the idea of relexification intriguing.

${ }^{10}$ As far as reception is concerned, comprehension can intervene at different levels, ranging from the general to the very precise. Compare the use of the 'passé surcomposé' (spoken in the Franco-provençal area, in France and in Switzerland) such as je l'ai eu fait mais je le fais plus depuis longtemps: $1^{\text {st }}$ level (general), 'past'; $2^{\text {nd }}$ level (more sophisticated), 'remote past aspect'.

${ }^{11}$ The borrowing of discourse markers, conjunctions, or logical particles are all indicators of intensive language contact (there are attestations of but and so in, for example, Ontarian, Acadian and Cadian French, but not in Quebec French). Weinreich (1953) has categorized such examples as 'free for symbolic investissment' as their borrowing is not due to any lexical gap.
} 
of Welmers, who stated that 'Some of the changes that have taken place in each [language] are internal [...]. Some of the changes, on the other hand, may be, and usually are, the result of external influence' (1970:2) would probably benefit from reassessment and, as Farrar \& Jones (2002) argue, a more pluralist approach to the explanation of language change seems to be warranted. We conclude with a consideration of three points that stand at the heart of this discussion.

\subsection{Contact-induced change}

1) Sociolinguistic arguments appear to be more clear-cut than structural ones, as agency (namely the role of the speaker as agent), is a leading force in the process of borrowing and change. We agree with Thomason (1997), who states that, when structural and sociolinguistic trends both intervene, then it is the latter which will tend to predominate. ${ }^{12}$ Contact usually affects everyday spoken varieties, which are mostly used and transmitted via social networks, and their existence outside formal teaching and writing means that they are able to escape normative pressures. These varieties display considerable amounts of variation and it is always necessary to establish the identity of each speaker in a given corpus in terms of age, education, mode of acquisition, frequency of use and so forth and also that of his/her network(s), and - a factor not hitherto considered in this paper-the sociolinguistic setting. Studies of Acadian and Ontarian French, in particular, have made clear the importance of differentiating between a frequent user of French, an occasional speaker and a semi-speaker (the latter usually restricted to home usage). The linguistic outcome in these cases will all differ considerably: compare, for example a study undertaken of, on the one hand, the French of Quebec, which is quite well-established and functions as an everyday language of the speech community and, on the other, that spoken in Prince Edward Island, where French is obsolescent and is now quite seldom spoken — at least as their only language — by young people.

2) Sociolinguistic considerations involve representations and ideology as much as they do actual socio-demographic (quantifiable) facts. Speakers have feelings about their language(s), for example loyalty towards their mother tongue, or the desire to resist the use of a dominant language, and these feelings are central to their language attitudes;

3 ) In order to establish exactly what is innovative in a language, the reference point should never be the standard language ('Standard French'), but rather the everyday, casual variety of different countries, including France ('ordinary', colloquial, or 'popular' French). Moreover, as far as historical data are concerned, that which can be reconstructed of the variety of French spoken at the time of emigration and which has led to the modern varieties of extra-Hexagonal French should be carefully scrutinized so that, before assuming that any phenomenon is innovative or contactbased, it is necessary to consider it within both its historical and geographical context.

\subsection{The study of languages and language change}

Over and above the opposition and interface between internal and sociolinguistic factors, this paper has refered to principles which could conceivably be proposed as possible universals of language change - such as how human beings interact in ordinary circumstances. This leads us to question the idea of whether a language could evolve 'endogenously', as some early commentators of language change, such as the Neogrammarians seemed eager to suggest. It is immaterial to speculate as to the possible nature of the putative endogenous evolution of French as, strictly speaking, no endogenous evolution can ever occur. Language always evolves in a social context, which necessarily implies contact between speakers, ie between linguistic varieties if not between languages themselves. For even if the language used by different people does not differ, their 'way of speaking', surely will. Weinreich's exclusively structural focus failed to consider this point and,

\footnotetext{
${ }^{12}$ See, for example, Thomason (1997:5): 'In each case the failure to fit the predicted linguistic situation is explained by a confounding social factor'.
} 
arguably, the use of terms such as 'drift' and 'trends' could be seen as problematic for this very reason. Furthermore, even more ambiguity surrounds the use of terms such as "needs" ${ }^{13}$ or 'optimality', as it is unclear whether they apply primarily to structures or to strategies used by speakers.

In conclusion, we hope to have demonstrated that grammarians of French (and perhaps of other languages, though we are wary of overgeneralising) may sometimes be overly quick to explain away as interference 'unusual' phenomena in non-standard and/or geographically peripheral varieties [to France]), even when such an explanation appears to contradict empirical data. Their eagerness may stem from the fact that interference enables the idea of linguistic homogeneity - and, perhaps, some 'purity' - to be preserved. History has shown that French grammarians, in particular, have a well established dislike of variation, which is so remote from their conception of what a language should be, and tend instead to prefer 'external' explanations for such phenomena. In our view, this may lead them to forget, or at least to overlook, the role of the speaker in language change.

\section{References}

Bauche, Henri. 1920. Le langage populaire. Paris: Payot.

Brasseur, Patrice (ed.). 1998. Français d'Amérique. Variation, créolisation, normalisation, Actes du colloque Les français d'Amérique du Nord en situation minoritaire, Université d'Avignon: Centre d'études canadiennes CECAV.

Brasseur, Patrice. 1998. De l'ellipse du pronom personnel aux formes verbales non marquées dans les parlers acadiens. In Brasseur (ed.), 1998. 75-91.

Brasseur, Patrice \& Anika Falkert (eds.). 2005. Français d'Amérique : approches morphosyntaxiques. Paris: L'Harmattan.

Brunot, Ferdinand \& Charles Bruneau. 1956. Précis de grammaire historique de la langue française. Paris: Masson.

Chaudenson, Robert. 1998. Variation, koïnèisation, créolisation: français d'Amérique et créoles. In Brasseur (ed.). 1998. 163-179.

Chaudenson, Robert, Raymond Mougeon \& Edouard Beniak. 1993. Vers une approche panlectale de la variation du français. Paris: Didier-Erudition.

Chevalier, Gisèle \& Isabelle Cossette. 2002. 'Comme', tic ou marqueur d'oralité ?, Port Acadie, Revue interdisciplinaire en Etudes acadiennes $=$ An Interdisciplinary Review in Acadian Studies, $3: 65-87$.

Chevalier, Gisèle \& Michael Long. 2005. Finder out, pour qu'on les frig pas up, comment c'qu'i workont out : les verbes à particule en chiac. In Brasseur \& Falkert (eds.). 2005. 201-212.

Farrar, Kimberley \& Mari C. Jones. 2002. Introduction. In Mari C. Jones \& Edith Esch (eds.), Language Change. The interplay of internal, external and extra-linguistic factors, 1-16. Berlin - New York: Mouton de Gruyter.

\footnotetext{
${ }^{13}$ Note that in this context, 'needs' $=$ Fr. 'besoins', a term adapted to the linguistic context by the Swiss scholar Henri Frei.
} 
Frei, Henri. 1929. La grammaire des fautes. Geneva: Slatkine.

Gadet, Françoise. 2006. L'ordre de la langue dans le sociolinguistique, Sociolinguistica 20:49-57.

Goffman, Erving. 1981. Forms of talk. Philadelphia: University of Pennsylvania Press.

Johanson, Lars. 2002. Do Languages Die of 'Structuritis'? On the Role of Code-Copying in Language Endangerment, Rivista di Linguistica 14.2:249-270.

Jones, Mari C. 2000. The subjunctive in Guernsey Norman French, Journal of French Language Studies 10.2:177-203.

Jones, Mari C. 2001. Jersey Norman French. A linguistic study of an obsolescent dialect. Oxford, Boston: Blackwell.

Jones, Mari C. 2002. 'Mette a haout dauve la grippe des Angllaïs: convergence on the Island of Guernsey'. In Mari C. Jones \& Edith Esch (eds.), Language Change. The interplay of internal, external and extra-linguistic factors, 143-168. Berlin - New York: Mouton de Gruyter.

King, Ruth. 1989. On the social meaning of the linguistic variability in language death situations: variation in Newfoundland French. In Nancy C. Dorian (ed.), Investigating obsolescence, 139-148. New York: Cambridge University Press.

King, Ruth. 1991. WH-words, WH-questions and Relative Clauses in Prince Edward Island Acadian French, Canadian Journal of Linguistics/Revue canadienne de linguistique 36:6585.

King, Ruth \& Yves Roberge. 1990. Preposition Stranding in Prince Edward Island French, Probus 2:351-369.

Lass, Roger. 1997. Historical Linguistics and Language Change. Cambridge: Cambridge University Press.

Laurier, Michel. 1989. Le subjonctif dans le parler franco-ontarien : un mode en voie de disparition?. In Raymond Mougeon \& Edouard Beniak (eds.), Le français canadien parlé hors Québec: aperçu sociolinguistique, 105-126. Québec: Presses de l'Université Laval.

Maher, Julianne. 1989. A crosslinguistic study of language contact and language attrition. In Nancy C. Dorian (ed.), Investigating Obsolescence, New York: Cambridge University Press.

Mühlhäusler, Peter. 1974. Pidginization and Simplification of Language, Series B, Vol. 26. Canberra: Pacific Linguistics.

Neumann-Holzschuh, Ingrid. 2005. Le subjonctif en français acadien. In Brasseur \& Falkert (eds.), 125-144.

Perrot, Marie-Eve. 1992. Fonctionnement du marqueur comme à partir d'un corpus "'chiac" (région de Moncton, Canada). In Approches énonciatives de l'énoncé complexe, 21-30. Louvain, Paris: Peeters.

Remacle, Louis. 1952. Syntaxe du parler wallon de la Gleize, Vol. 1. Paris: Les Belles Lettres.

Roberge, Yves \& Nicole Rosen. 1999. Preposition stranding and que-deletion in varieties of North American French, Linguistica Atlantica 21:153-168. 
Rottet, Kevin. 2001. Language Shift in the Coastal Marshes of Louisiana, Vol. 8, Studies in Ethnolinguistics. New York: Peter Lang.

Rottet, Kevin. 2005. Variation et étiolement en français cadien: perspectives comparées. In Albert Valdman, Julie Auger \& Deborah Piston-Hatlen (eds.), Le français en Amérique du Nord, état présent, 243-260. Québec: Presses de l'Université Laval.

Sankoff, Gillian \& Pierrette Thibault. 1977. L'alternance entre les auxiliaires avoir et être en français parlé à Montréal, Langue française 34:81-108.

Sankoff, Gillian. 2001. Linguistic Outcomes of Language Contact. In Jack Chambers, Peter Trudgill \& Natalie Schilling-Estes (eds.), The Handbook of Language Variation and Change, 638-668. Oxford: Blackwell.

Sasse, Hans-Jürgen. 1992. Language Decay and contact-induced change : Similarities and differences. In Matthias Brenziger (ed.), Language Death: Factual and Theoretical explorations with special reference to East Africa, 59-80. New York: Mouton de Gruyter.

Stäbler, Cynthia. 1995. La vie dans le temps et asteur, Corpus de français de Louisiane. Tübingen: Niemeyer.

Thomason, Sarah G. 1997. On the unpredictability of contact effects, downloadable from wwwpersonal.umich.edu/ thomason/papers/papers.html (accessed January 2008).

Thomason, Sarah G. 2008. Social and linguistic factors as predictors of contact-induced change, (This volume).

Thomason, Sarah G. \& Terrence Kaufman. 1988. Language Contact, Creolization and Genetic Linguistics. Berkeley - Los Angeles - London: University of California Press.

Tremblay, Mireille. 2005. Back en français acadien : archaïsme ou innovation?. In Brasseur \& Falkert (eds.), 2005. 263-273.

Vinet, Marie-Thérèse. 1996. Lexique, emprunts et invariants: une analyse théorique des anglicismes en français du Québec, Revue québécoise de linguistique 24-2:165-181.

Weinreich, Uriel. 1953. Languages in Contact. The Hague: Mouton.

Welmers, William E. 1970. Language change and language relationships in Africa, Language Sciences 12:1-8. 